\section{Problematika Penerapan Tanda Baca dan Pola Kalimat dalam Produk Peraturan Daerah}

\author{
Lilis Hartini* dan Dadang Sudana \\ Program Studi Linguistik \\ Universitas Pendidikan Indonesia \\ *lilishartini90@gmail.com
}

\begin{abstract}
ABSTRAK
Struktur bahasa Indonesia memusatkan perhatiannya pada tata bahasa yang sesuai dengan standardisasi bahasa. Struktur bahasa yang sudah memenuhi syarat kaidah bahasa Indonesia yang berlaku menerapkan pola kalimat yang sempurna. Pola kalimat akan sempurna apabila ditunjang oleh tanda baca yang sesuai dengan makna sintaksiknya. Struktur bahasa seperi ini dikategorikan sebagai bahasa yang baik dan benar. Permasalahan inti dari penelitian ini adalah bagaimana problematika tanda baca dan pola kalimat yang diterapkan dalam produk peraturan daerah dan bagaimana kekeliruan bahasa dapat terjadi pada produk Peraturan Daerah. Penelitian ini bertujuan untuk mendeskripsikan penerapan pola kalimat dan kekeliruan bahasa dalam produk peraturan daerah.
\end{abstract}

Melalui metode deskriptif dengan mengambil pendekatan kualitatif interpretatif berdasarkan kepustakaan ditemukan bahwa terdapat beberapa aturan hukum yang tidak menerapkan tanda baca dan pola kalimat yang sesuai dengan strandardisasi bahasa, sehingga komunikasi hukum menjadi kurang baik. Ini berimbas pada kekeliruan penggunaan bahasa pada teks-teks hukum. Hasil data yang dianalisis tersebut disajikan melalui contoh yang relevan dengan keadaan hukum dewasa ini.

Hasil penelitian menunjukkan terdapat dua problematika dalam produk hukum. Pertama, problematika penerapan tanda baca dan pola kalimat pada teks hukum terdapat pada kebiasaan masyarakat hukum yang tidak mau beranjak dari budaya untuk menyalin kembali istilah-istilah hukum atau teks-teks hukum dari wacana hukum sebelumnya Kedua, berhubungan dengan kekeliruan berbahasa yang sering menyimpang dari struktur tata bahasa sehingga terkesan penulisan aturan terlampau jauh dari kepraktisan berbahasa. Hal ini mengakibatkan kekeliruan struktur bahasa dalam produk hukum karena kaidah bahasa Indonesia yang baku telah dilanggar.

Kata Kunci: Standardisasi; Produk Hukum; Perda

\title{
PENGANTAR
}

Bahasa terdiri atas rangkaian kalimat dan kalimat merupakan rangkaian kata-kata yang disusun berdasarkan struktur bahasa yang berlaku sehingga memiliki makna. Apabila struktur bahasa yang digunakan tidak baik atau tidak sesuai kaidah bahasa yang berlaku, maka makna kalimat juga menjadi tidak jelas atau memunculkan makna ambigu. Dengan demikian akan terjadi penafsiran yang berbeda. Apabila sebuah ilmu pengetahuan telah salah ditafsirkan atau salah dalam pemahaman oleh pembaca yang terjadi adalah kesalahan penerapan ilmu pengetahuan tersebut dalam kehidupan sehari-hari. Penemuan intelektual yang sebenarnya bermanfaat bagi manusia lain ternyata tidak bermanfaat karena kesalahan struktur kalimat.

Hal ini berlaku juga untuk bahasa hukum. Bahasa hukum adalah salah satu ragam bahasa ilmiah yang penggunaannya harus sesuai dengan struktur bahasa yang berlaku. (Hartini, 2019) Apalagi bahasa hukum itu merupakan wakil dari bahasa Negara. Sebagai bahasa Negara bahasa hukum harus taat asas terhadap semua bentuk kaidah pembakuan bahasa Indonesia yang berlaku. Tidak disangkal lagi bahasa hukum haruslah mewakili bahasa Indonesia yang baik dan benar.

Penerapan bahasa hukum membawa problem bagi struktur bahasa Indonesia karena bahasa hukum sering menyalahi kaidah tata bahasa, baik dalam susunan kalimat atau penggunaan 
istilah yang kurang lazim digunakan dalam pengertian yang umum. Bahasa Indonesia yang dipakai dalam dunia hukum sering tidak berhasil memancarkan kandungan atau isi hukum dengan baik. Problematika itu ada ketika seseorang menemui kesulitan menangkap makna hukum dalam sebuah peraturan. Misalnya, masyarakat yang awam hukum tidak mengerti batasan-batasan dan akibat-akibat dari perumusan aturan yang tertulis karena bahasa hukum tidak lugas, malah berputar-putar dengan menggunakan kalimat yang panjang. Jika tidak dibaca dengan cermat dan hati-hati, maknanya bisa jadi berbeda dengan makna hukum yang dimaksud. Di sini terlihat adanya kegagalan komunikasi.

Kekeliruan berbahasa tidak hanya ditemukan dalam penyampaian informasi baru berupa produk perundang-undangan baru, tetapi sering ditemukan dalam kehidupan sehari-hari. Kesalahan pemilihan kata, penyusunan struktur kalimat dalam berbahasa disebabkan banyak faktor. Jika mencari kesalahan tanpa memerhatikan pembetulannya, maka tidak akan pernah diketahui hal yang benar yang akhirnya kesalahan tetap berjalan. Salah satu cara memperbaiki kekeliruan berbahasa yang terjadi dalam produk perundang-undangan adalah dengan memberi penekanan pada inti materi yang akan disampaikan.

Berdasarkan penelitian, ada kecenderungan naskah pada produk-produk hukum itu sama dari waktu ke waktu. Misalnya, dalam naskah Peraturan Daerah (Perda) Kota Bandung dirumuskan:

Peraturan Daerah ini mulai berlaku pada tanggal diundangkan. Agar setiap orang mengetahuinya, memerintahkan pengundangan Peraturan Daerah ini dengan penempatannya dalam Lembaran Daerah Kota Bandung.

Teksnya selalu ditemukan pada Perda-Perda lainnya. Jika teksnya tidak sesuai dengan kaidah pembakuan bahasa akan menyebabkan kerancuan bahasa terus-menerus dilakukan. Padahal masa berlaku suatu produk hukum selalu diperbaharui tetapi sebagian bahasanya sering diulang-ulang.

Fenomena kekeliruan dan permasalahan yang sering terjadi dalam menuangkan gagasan hukum dalam teks perundang-undangan, salah satunya dapat dilihat dari aspek tata bahasa, baik dari aspek morfologi maupun sintaksis. Kesalahan berbahasa tidak hanya ditemukan dalam penyampaian informasi baru berupa naskah perundang-undangan baru, tetapi sering ditemukan dalam kehidupan sehari-hari. Kesalahan pemilihan kata, tanda baca, maupun penyusunan pola kalimat dalam berbahasa disebabkan banyak faktor. Salah satu faktornya adalah kurang terampil menggunakan struktur tata bahasa Indonesia secara benar. Produk peraturan daerah menarik untuk diteliti karena pada umumnya kalimat-kalimat hukum dalam produk peraturan daerah mengalami kekeliruan di bidang sintaksis.

Sintaksis adalah sistem kaidah dan kategori yang memungkinkan kata-kata dikombinasikan untuk membentuk kalimat. Konstruksi sintaksis merupakan proses pengaturan kata-kata atau kelompok kata menjadi kesatuan bermakna, yang terdiri atas frasa, klausa, dan kalimat (Ba'dulu, 2005). Adapun kalimat adalah satuan gramatikal yang dibatasi oleh adanya jeda panjang yang disertai oleh nada akhir turun atau naik(Ramlan, 2005). Sedangkan menurut(Bloomfield, 1993) kalimat adalah suatu bentuk linguistik, yang tidak termasuk ke dalam suatu bentuk yang lebih besar karena merupakan suatu konstruksi gramatikal.

Berdasarkan latar belakang di atas maka rumusan masalah dibagi ke dalam dua bagian, pertama, bagaimana problematika penggunaan ejaan di dalam produk Perda? Kedua, bagaimana akurasi penggunaan pola kalimat pada produk perundang-undangan di Indonesia, khususnya pada peraturan daerah? Penelitian ini bertujuan untuk mendeskripsikan dan mengungkap problematika penggunaan ejaan dalam produk perda, yang mencakup akurasi penggunaan pada tanda baca dan pola kalimat. Studi terdahulu tentang kajian morfosintaksis terhadap perundang-undangan pernah dilakukan oleh (Badudu, 1988), (Iskar, 2004), dan tesis dari (Abdulman, 2011) .

Teori yang digunakan untuk mengkaji masalah ini berdasarkan Tata Bahasa Baku Bahasa Indonesia (1988), teori Sintaksis dari (Ramlan, 2005) untuk membedah keakurasian penggunaan 
pola kalimat, dan Ejaan Bahasa Indonesia (2015) untuk membedah masalah tanda baca dengan menggunakan metode deskriptif kualitiatif.

Sebagai pisau analisis dalam dalam penelitian ini adalah PUEBI dan konsep standardisasi bahasa pada struktur kalimat akan dijadikan dasar penelitian yang dilakukan.(1988) Pembakuan atau standarisasi bahasa adalah proses penentuan ukuran atau norma rujukan yang digunakan atau dapat digunakan sebagai kerangka rujukan atau patokan dalam penggunaan bahasa oleh masyarakat pemakai bahasa yang bersangkutan. Norma itu ditentukan oleh masyarakat pemakai bahasa yang bersangkutan sendiri atas dasar kesepakatan sosial sesuai dengan kebutuhan dan tingkat perkembangan.

Norma di atas berlaku untuk semua ragam bahasa standar, termasuk ragam bahasa keilmuan. Bahasa hukum termasuk ke dalam ragam bahasa keilmuan. Oleh karena, struktur bahasa yang baku itu mencakup bahasa yang benar menurut kaidah sehingga dapat menjawab permasalahan bahasa pada produk perundang-undangan. Di sini teks hukum berupa naskah perundangundangan dapat dimaknai berdasarkan konteks bahasa secara struktural yang sesuai fakta hukum dengan menerapkan kaidah pembakuan bahasa Indonesia yang baik dan benar.

Hal ini karena pikiran manusia bukanlah entitas tanpa struktur. Pikiran itu memiliki struktur, dan struktur pikiran tersebut terartikulasi dalam tata bahasa. Pengkomunikasian pikiran hanya mungkin dilakukan oleh yang memahami sistem tata bahasa. Hanya dengan sistem semacam inilah, pengkomunikasian pikiran menjadi mungkin. Struktur kalimat adalah pengaturan pola dalam bahasa secara sintagmatis. Struktur bahasa itu meliputi wacana, paragraf, kalimat, kata, fonem, dan morfem. Dalam suatu kajian bahasa yang berhubungan dengan struktur bahasa selalu dikaitkan dengan keteraturan berbahasa sehingga sering dikatakan bahwa pengkajian struktur bahasa tidak lepas dari struktur bahasa yang baku.

\section{ANALISIS DAN PEMBAHASAN}

Dalam Peraturan Daerah (Perda) banyak ditemukan kekeliruan penggunaan tanda baca dan pola kalimat. Menurut (Ramlan, 2005) sintaksis adalah bagian atau cabang dari ilmu bahasa yang mebicarakan seluk beluk wacana. Kalimat, klausa, dan frase. Berbeda dengan morfologi yang membicarakan seluk beluk kata dan morfem.

Berdasarkan hasil penelitian ditemukan beberapa problematika penggunaan ejaan, seperti bentukan kata dan tanda baca. Begitu juga dengan akurasi penggunaan pola kalimat. Kedua masalah ini ditemukan dalam produk Perda.

Pada kesempatan ini, penulis mengupas Perda No. 08 Tahun 2016 tentang Pembentukan dan Susunan Perangkat Daerah Kota Bandung; Perda no. 08 Tahun 2017 tentang Perubahan atas Peraturan Daerah Kota Bandung No. 15 Tahun 2012 tentang Penyelenggaraan Menara Telekomunikasi dan Retribusi Pengendalian Menara Telekomunikasi; dan Perda No. 4 Tahun 2019 tentang Pemajuan, Perlindungan, dan Pemenuhan Hak-Hak Penyandang Disabilitas.

\section{Problematika Penggunaan Ejaan pada Produk Perda}

Bagi para legal drafting membangun susunan kata-kata dari sumber pembendaharaan yang ada, sebagai simbol-simbol komunikasi yang diterapkan melalui kata-kata tertulis sering kali mengabaikan tata bahasa demi penegakan batasan. Batasan-batasan inilah yang sering mengganggu struktur bahasa Indonesia yang baik dan benar karena struktur bahasa yang taat asas terhadap standardisasi bahasa menjadi diabaikan, seperti pada contoh berikut:

a. Pada Pasal 7 ayat (3) Perda No. 08 Tahun 2016 tentang Pembentukan dan Susunan Perangkat Daerah Kota Bandung terdapat struktur bahasa yang tidak taat asas terhadap norma pembakuan bahasa. Bunyi Pasal tersebut adalah:

Dalam hal rumah sakit Daerah belum menerapkan pengelolaan keuangan badan layanan umum daerah, pengelolaan rumah sakit Daerah tetap bersifat otonom dalam perencanaan, pelaksanaan, dan pertanggungjawaban keuangan. 
Dalam PUEBI terdapat aturan tentang huruf kapital, yaitu huruf kapital digunakan sebagai huruf pertama nama lembaga atau dokumen resmi negara. Perhatikan frasa yang digarisbawahi, di situ tertulis rumah sakit Daerah, seharusnya Rumah Sakit menggunakan huruf kapital. Oleh karena, Rumah Sakit Daerah termasuk ke dalam lembaga negara.

Selanjutnya, struktur kalimat pada teks di atas pun menerapkan diksi yang kurang tepat. Coba perhatikan bentuk frasa dalam hal, pada awal kalimat di atas. Jika diperhatikan makna dan struktur kalimatnya memang sudah sesuai dengan yang diharapkan jika maksudnya adalah dalam peristiwa atau dalam keadaan. Akan tetapi, frasa dalam hal penerapannya kurang tepat disimpan pada awal kalimat karena dalam pembakuan bahasa frasa dalam hal berfungsi sebagai kata penghubung antarkalimat yang diikuti tanda koma (, jika digunakan pada awal kalimat dan itu pun frasanya terdiri dari tiga kata, yaitu Dalam hal ini. Pilihan kata (diksi) yang tepat untuk kalimat di atas dengan menggunakan kata walaupun.

\section{b. Pada ketiga Perda yang diteliti terdapat beberapa bentuk bersaing, seperti;}

Walikota (Perda No. 08/2016) dan (Perda No.04/2019) >< Wali kota (Perda No. 08/2017) Dalam PUEBI disebutkan bahwa unsur gabungan kata yang lazim disebut kata majemuk, termasuk istilah khusus, ditulis terpisah. Frasa Wali Kota adalah bentuk baku dalam bahasa Indonesia.

Bentuk bersaing yang terdapat dalam bahasa Indonesia merupakan kekayaan bahasa yang sering membingungkan para pengguna bahasa. Oleh karena, setiap pengguna bahasa sering salah dalam membedakan mana bentuk baku dan mana bentuk nonbakunya, seperti pada kata subyek dengan subjek, positip dengan positif, sistem dengan sistim, azas dengan asas, sertipikat dengan sertifikat, kadaluarsa dengan kedaluarsa, dan masih banyak yang lainnya.

Mengapa bahasa Indonesia mengenal bentuk bersaing? Ini berhubungan dengan sejarah bahasa Indonesia. Ada dua keadaan yang menyebabkan banyak bentuk bersaing dalam bahasa Indonesia. Pertama, Indonesia pernah dijajah oleh bangsa Belanda dan bangsa Jepang sehingga banyak kosakata bahasa yang tadinya menggunakan ejaan bahasa Belanda menjadi ejaan bahasa Indonesia, misalnya kata hipotesa, analisa itu asalnya dari bahasa Belanda, dan kata-kata tersebut terdapat dalam ejaan Van Opuysen (1901). Sejak diganti dengan ejaan Bahasa Indonesia yang disempurnakan (EYD, 1973; sekarang EBI, 2015) maka proses pembentukan istilah harus mengacu ke dalam bahasa Inggris. Jadi akhirnya kata hipotesa dan analisa diganti dengan hipotesis dan analisis. Kedua, bangsa Indonesia terdiri dari berbagai suku bangsa yang mempunyai bahasa ibu (daerah) yang beragam sehingga cara pengucapan pun bisa saja salah, seperti kata positif dibaca oleh orang dari daerah Sunda menjadi positip. Jadi bentuk bakunya adalah hipotesis, analisis, dan positif.

c. Ditemukan bentuk terikat, seperti sub urusan [Pasal 3b (2)] non formal [Pasal 6, ayat (2)], dan non perizinan [Pasal 13, ayat (3)]. Bentukan sub-, non-, in-, antar-, pra-, pasca- adalah bentuk terikat sehingga tidak dapat berdiri sendiri dan akan mempunyai makna jika dilekatkan pada kata yang diikutinya. Seharusnya suburusan, nonformal, dan nonperizinan, karena bentuk terikat melekat dengan kata yang diikutinya.

d. Berikut adalah kekurangcermatan dalam penggunaan tanda titik (.)

\section{H. BAMBANG SUHARI, SH}

Pada PUEBI disebutkan bahwa singkatan nama orang, gelar, sapaan, jabatan, atau pangkat diikuti dengan tanda titik pada setiap unsur singkatan itu. Jadi bentuk bakunya adalah $\mathrm{H}$. BAMBANG SUHARI, S.H. Oleh karena tanda titik (.) di sana mempunyai pengertian masih ada kepanjangannya, yaitu arjana dan ukum sebagai kepanjangan dari Sarjana Hukum. Setiap tanda baca dalam membantu pembentukan sebuah kalimat mempunyai makna masing-masing. Misalnya, tanda titik (.) selain untuk hentian akhir juga untuk menandakan akhir singkatan. 
e. Tanda koma (,) sebagai jeda tidak hanya digunakan dalam hentian sementara tetapi juga dapat digunakan sebagai rincian. Perlu diperhatikan juga bahwa tanda baca itu harus selalu melekat pada kata yang diikutinya.

Pada bagian kedua, Pasal 3b, ayat (10) dan ayat (14) terdapat penggunaan tanda koma yang tidak baku.

f. Dinas Pangan dan Pertanian tipe A menyelenggarakan urusan pemerintahan bidang pangan, bidang pertanian dan bidang perikanan; ....

g. Dinas Komunikasi dan Informatika tipe A, menyelenggarakan urusan pemerintahan bidang komunikasi dan informatika, bidang persandian dan bidang statistik;....

Untuk membagi atau merinci suatu kategori dalam kalimat harus mengacu pada PUEBI, seperti tanda koma dipakai di antara unsur-unsur dalam suatu pemerincian atau pembilangan. Jika kita merinci (mengklasifikasi) dua hal, misalnya $a$ dan $b$ maka sebelum dan tidak perlu menggunakan koma (,) tetapi jika rinciannya lebih dari dua maka sebelum dan harus diberi koma (,). Perhatikan ketiga bentuk aturan yang dicetak miring di atas. Kalimat tersebut menjadi baku apabila sebelum dan diberi tanda koma, yaitu (a) bidang pangan, bidang pertanian, dan bidang perikanan dan (b) bidang komunikasi dan informatika, bidang persandian, dan bidang statistik. Jika sebelum kata perangkai dan tidak diberi tanda koma (.) maka artinya bahwa rinciannya terdiri dari dua kategori, yaitu (a) bidang pertama pangan, bidang kedua pertanian dan bidang perikanan. Di sini jelas bahwa kedua bidang sesudahnya satu kategori yang dapat dibedakan dari bidang pertama, yaitu bidang pangan. Padahal menurut logika bahasa bidang pangan, bidang pertanian, dan bidang perikanan itu mempunyai ciri, materi, dan fungsi yang berbeda satu sama lain. Begitu juga dengan rincian kategori (b), yaitu bidang pertama komunikasi dan informatika, bidang kedua persandian dan statistik. Sekali lagi, menurut logika bahasa bidang ketiga kategori tersebut mempunyai ciri, materi, dan fungsi yang berbeda satu sama lain. Tentu saja karena ciri, materi, dan fungsi satu sama lain berbeda maka rinciannya tiga kategori bukan dua kategori.

\section{Akurasi Penggunaaan Pola Kalimat}

Berikut adalah temuan tentang akurasi penggunaan pola kalimat:

\section{a. Penggunaan Definisi/ Batasan}

Perda No.08 Tahun 2016, Bab I, Pasal 1, ayat (12) berbunyi: Unit Pelaksana Teknis yang selanjutnya disingkat UPT adalah unit pelaksana teknis pada Dinas dan Badan yang dibentuk sesuai dengan kebutuhan. Terdapat aturan membuat definisi dalam bahasa Indonesia. Salah satunya adalah subjek pelaku tidak boleh diulang ketika didefinisikan. Pada pasal di atas Unit Pelaksana Teknis didefinisikan dengan unit pelaksana teknis. Ada baiknya definisi di atas menjadi Unit Pelaksana Teknis yang selanjutnya disingkat UPT adalah satuan organisasi pada Dinas dan Badan yang dibentuk sesuai dengan kebutuhan.

b. Probematika selanjutnya adalah para pembuat aturan yang memproduksi hukum tidak mau melepaskan diri dari kebiasaan menyalin teks hukum pada aturan sebelumnya.

Contoh: bahwa berdasarkan pertimbangan sebagaimana dimaksud dalam huruf a, perlu menetapkan Peraturan Daerah tentang....

c. Pada Perda No. 4/2019 di dalam penjelasan: Ayat (2) Huruf b Angka 1 Yang dimaksudkan dengan "rumah aman (safe house)" adalah rumah yang diperuntukan untuk melindungi Penyandang disabilitas yang menjadi korban kekerasan.

Kata diperuntukan seharusnya ditulis diperuntukkan karena berasal dari kombinasi afiks diper-kan yang ditambah kata dasar untuk. Kata diperuntukan untuk adalah bentukan kata yang mubazir karena kata kelompok kata tesebut mempunyai kata dasar yang sama, yaitu untuk. Kalimat di atas seharusnya: 
Yang dimaksud dengan 'rumah aman (safe house)" adalah rumah yang disediakan untuk melindungi Penyandang disabilitas yang menjadi korban kekerasan.

d. Pada Pasal 48 Peraturan Daerah Kota Bandung Nomor 15 Tahun 2012 tentang Penyelenggaraan Menara Telekomunikasi dan Retribusi Pengendalian Menara Telekomunikasi terdapat kalimat:

(4) Berdasarkan RPMT memperhitungkan 2 (dua) Indeks Variabel:

a. Zonasi; dan

b. Jenis Menara.

Dalam struktur gramatikal (morfologi), bentuk kata hitung diberi imbuhan memper-kan adalah bentukan yang benar, yaitu memperhitungkan dan dimasukkan ke dalam kelas kata kerja aktif. Akan tetapi, ketika bentukan itu berhubungan dengan struktur morfosintaksis maka maknanya akan menjadi rancu karena proses pembentukan kalimatnya menjadi salah sehingga makna kalimatnya pun menjadi keliru. Perhatikan bentuk kalimatnya

Berdasarkan RPMT memperhitungkan 2 (dua) Indeks Variabel:

Jika ingin membuktikan keakurasian kalimat adalah dengan menanyakan unsur-unsur pembentuk kalimat, seperti:

- Cara menanyakan subjek dengan kalimat Siapa yang memperhitungkan? maka akan membentuk jawaban berdasarkan RPMT. Ini adalah jawaban yang keliru karena maksud dari kalimat di atas yang menjadi subjeknya adalah RPMT. Jadi kalimat tersebut seharusnya RPTM memperhitungkan 2 (dua) Indeks Variabel.

- Jika jawaban penekanannya diawali dengan menggunakan kata berdasarkan, maka pertanyaan untuk subjek menjadi Indeks variabel diperhitungkan berdasarkan apa? Jawabannya adalah RPTM. Jadi kalimat tersebut seharusnya Berdasarkan RPTM diperhitungkan 2 (dua) indeks variabel.

e. Begitu juga dengan kalimat berikut:

a. bahwa berdasarkan pertimbangan sebagaimana dimaksud dalam huruf a, perlu menetapkan Peraturan Daerah

Di sini jelas terlihat ketidakakurasian bahasa, yaitu subjek yang dilesapkan. Jadi di sini unsur pembentuk kalimat tidak lengkap. Dalam tata bahasa Indonesia yang berdasar pada struktur gramatikal yang bertaat asas maka sebelum predikat yang berperan sebagai kata kerja aktif, seperti pada kata memperhitungkan atau menetapkan maka subjeknya tidak dapat dilesapkan atau tidak boleh dihilangkan. Beda lagi, jika predikatnya berperan sebagai kata kerja pasif, seperti pada kata diperhitungkan atau ditetapkan maka subjek boleh hilang karena di- (sebagai bentukan pasif) sudah berperan sebagai subjek.

Untuk memeriksa kekeliruan struktur kalimat di atas dengan membuat pertanyaan sebagai berikut:

b. Siapa yang menetapkan Peraturan Daerah? Apakah jawabannya perlu atau Berdasarkan pertimbangan siap? Ternyata kedua jawaban tersebut keliru karena yang diinginkan dari pertanyaan tersebut jawabannya adalah subjek. Hal ini merupakan salah satu kelemahan kalimat hukum atau pembuat aturan hukum karena dalam teks hukum sering ditemukan terminologi yang terlalu luas.

c. Pertanyaan yang keliru untuk kalimat di atas adalah Peraturan Daerah menetapkan berdasarkan apa? tetapi seharusnya pertanyaannya adalah Peraturan Daerah ditetapkan berdasarkan apa? Mengapa keliru? karena akan muncul pertanyaan apa yang ditetapkan? Kalimat itu menjadi baik dan benar jika redaksinya bahwa 
berdasarkan pertimbangan sebagaimana dimaksud dalam huruf a, perlu ditetapkan Peraturan Daerah ....

d. Berikut adalah dua kalimat panjang yang disatukan dan sebetulnya berfungsi sebagai satu paragraf. Kalimat panjang berikut menjadi tidak akurat ketika tidak memanfaatkan tanda titik (.) yang memisahkan antara kalimat panjang pertama yang berisi ide pokok (dibentuk Peraturan Daerah Kota Bandung Nomor 15 Tahun 2012 tentang Penyelenggaraan Menara Telekomunikasi dan Retribusi Pengendalian Menara Telekomunikasi) dan kalimat panjang kedua sebagai kalimat pengembang. Agar kalimat berikut menjadi efektif maka harus difungsikan sebagai paragraf, yang terdiri dari dua kalimat, yaitu sebelum kata namun diberi tanda titik (.)

Menimbang :bahwa dalam rangka menata, mengendalikan, dan mengawasi pembangunan dan pengoperasian menara telekomunikasi, telah dibentuk Peraturan Daerah Kota Bandung Nomor 15 Tahun 2012 tentang Penyelenggaraan Menara Telekomunikasi dan Retribusi Pengendalian Menara Telekomunikasi, namun dalam perkembangannya telah terbit Putusan Mahkamah Konstitusi Nomor 46/PUU-XII/2014 yang membatalkan penjelasan Pasal 124 Undang-Undang Nomor 28 Tahun 2009 tentang Pajak Daerah dan Retribusi Daerah, sehingga Peraturan Daerah termaksud yang perhitungan retribusinya mengacu pada penjelasan Pasal124 Undang-Undang Nomor 28 Tahun 2009 tentang Pajak Daerah dan Retribusi Daerah perlu dilakukan perubahan;

f. Pada bab IV tentang Staf Ahli, Pasal 10 ayat (2) terdapat ketidakakurasian karena staf ahli pasti berada di bawah Wali Kota. Jadi lebih baik tidak disebutkan lagi. Berikut adalah kalimatnya:

Staf ahli berada di bawah dan bertanggungjawab kepada Walikota dan secara administratif dikoordinasikan oleh sekretaris Daerah.

Frase berada di bawah menjadi tidak logis karena tidak diikuti dengan subjeknya. Ketidakakuratan itu akan dipahami jika ada pertanyaan apa yang di bawah? Mengapa berada di bawah? Di bawah apa? Sebetulnya kita tahu maksud frase tersebut tetapi penulisan frase berada di bawah menjadi ambigu.

Begitu juga dengan kata bertanggungjawab tidak baku penulisannya. Bentuk bakunya adalah bertanggung jawab. Bentuk dasar dari kata majemuknya adalah tanggung jawab bukan tanggungjawab kata tanggung diberi awalan ber- menjadi bertanggung. Oleh karena, tanggung jawab merupakan kata majemuk maka menjadi bertanggung jawab. Sebaiknya kalimat di atas menjadi:

Stafahli bertanggung jawab kepada Wali Kota dan secara administratif dikoordinasikan oleh Sekretaris Daerah.

atau

Staf ahli berada di bawah Wali Kota dan bertanggung jawab kepada Wali kota dan secara administratif dikoordinasikan oleh Sekretaris Daerah.

g. Salah satu kekeliruan yang harus segera diperbaiki oleh para ahli hukum adalah keakurasian dalam terminologi hukum. Berikut adalah contohnya:

Tiba-tiba pada Pasal 16 ayat (1), Perda No. 4/2019 terdapat singkatan PD, kalimatnya:

$P D$ yang mempunyai tugas pokok dan fungsi dalam bidang perencanaan menyusun rencana induk pelaksanaan pemajuan, pelindungan, dan pemenuhan hak-hak Penyandang Disabilitas.

Singkatan PD menyebar di beberapa pasal dan ayat tanpa dijabarkan kepanjangan dari PD. Penelitipun membaca teks penjelasannya. Ternyata singkatan PD tidak muncul. Ada beberapa frase yang mengarah pada istilah PD, yaitu Pemerintah Daerah, Peraturan Daerah, Perangkat Daerah, dan Penyandang Disabilitas. Istilah PD menunjuk pada makna 
di luar teks (kalimat). Istilah ini hanya diketahui oleh para pembuat aturan hukum di pemerintah daerah Yogyakarta.

h. Peraturan Daerah ini mulai berlaku pada tanggal diundangkan.

Agar setiap orang mengetahuinya, memerintahkan pengundangan Peraturan Daerah ini dengan penempatannya dalam Lembaran Daerah Kota Yogyakarta.

Ketidakakuratannya terdapat pada kata memerintahkan. Di sini subjek dilesapkan sehingga dapat mengundang pertanyaan Siapa yang memerintahkan? Apakah setiap orang atau Wali Kota? Kalau membaca redaksi kalimat di atas tentu saja jawabannya setiap orang tetapi apakah benar setiap orang mempunyai otoritas untuk memerintah?

Kebiasaan para pembuat aturan hukum ini menjamur pada setiap produk hukum. Bahkan istilah-istilah yang dipakai pun merupakan kelangsungan dari kebiasaan sebelumnya, baik kebiasaan birokrasi dalam pola pemerintahan maupun pemberian wewenang. Pemakaian dan penjabaran konsep seperti ini sudah lama diterima oleh masyarakat hukum dan dilestarikan dalam produk hukum. Penerapan struktur bahasa ini terjadi di setiap aturan hukum sehingga mengakibatkan pemakaian istilah hukum sangat kaku dan tidak luwes sehingga jika muncul pengertian baru atau konsensus baru di masyarakat maka akan diupayakan terlebih dahulu menampung pengertian atau konsensus baru tersebut dalam peristilahan hukum yang sudah ada.

Disadari atau tidak kebiasaan ini mengajarkan pada generasi hukum, seperti mahasiswa, akademisi hukum, bahkan pakar hukum selanjutnya untuk tidak berpikir kreatif karena budaya hukumnya hanya mengikuti struktur bahasa yang sudah ada. Apalagi jika penerapan struktur kaidah bahasa baku tidak ditaati maka kesalahan penyalinan akan terus terwarisi kepada generasi masyarakat hukum ke depannya. Misalnya, bentuk kata dimana, yang mana, hal mana, dari mana sering dipergunakan sebagai kata penghubung dalam bahasa hukum. Padahal fungsi kata dimana, yang mana, hal mana, dan dari mana sebagai kata tanya bukan kata penghubung.

Cara supaya terlepas dari kebiasaan mencantumkan kata atau frasa tersebut maka latihan menggunakan kata sambung (kata perangkai/ kata penghubung) sekaligus menghilangkan bentukan mana ketika membaca redaksi hukum yang terdapat kata dimana, yang mana, hal mana, dan dari mana. Metodenya adalah jika ditemukan kalimat yang berhubungan dengan waktu dengan kata dimana sebagai kata penghubungnya, maka ganti kata dimana dengan kata saat, waktu, atau ketika. Jika ditemukan kalimat yang berhubungan dengan tempat dengan kata dimana sebagai kata penghubungnya, maka ganti kata dimana dengan kata tempat. Jika ditemukan kalimat yang berhubungan dengan sebab akibat dengan kata dimana sebagai kata penghubungnya, maka ganti kata dimana dengan kata karena atau sebab. Begitu juga, jika ditemukan kalimat dengan frasa penghubungnya yang mana, hal mana, dan dari mana, maka hapus kata mananya karena kata yang, hal, dan dari merupakan kata penghubung.(Hartini, 2019)

\section{KESIMPULAN}

1. Masalah penggunaan ejaan dalam Peraturan Daerah adalah:

a. Terdapat beberapa kesalahan ejaan yang merujuk pada PUEBI, seperti penulisan huruf kapital; penulisan gabungan kata yang berkategori kata majemuk; penulisan bentuk terikat; juga penggunaan tanda baca titik dan koma. Kesalahan-kesalahan ini berdampak pada makna struktur kalimat hukum, misalnya dalam rincian, yang seharusnya tiga kategori menjadi dua kateori karena penulisan tanda koma yang tidak tepat. 
b. Bahasa hukum sering menyalahi kaidah tata bahasa karena kekurangmahiran berbahasa baku pembuat aturan dalam menuangkan gagasan ke dalam bentuk kalimat.

2. Masalah akurasi penggunaan pola kalimat pada produk Perda:

a. Ketidakakurasian penggunaan pola kalimat ditemukan pada batasan tentang suatu istilah hukum yang subjeknya selalu diulang, misalnya Unit Pelaksana eksis adalah Unit Pelaksana Teknis.

b. Produk hukum selalu mengulang teks-teks sebelumnya, mulai dari teks itu diproduksi sampai dengan sekarang. Sehingga jika teks aslinya berpola kalimat yang salah maka tidak pernah dibetulkan, sudah menjadi kebiasaan, dan dogma bagi masyarakat hukum. Bahkan mereka menganggap bahwa kesalahan tersebut sudah menjadi ciri khas hukum.

c. Hasil penelitian menunjukkan bahwa terdapat ketidakakurasian beberapa teks hukum dalam menggunakan pola kalimat sehingga kalimat yang dihasilkan menjadi tidak logis.

d. Ada ketidakajegan dalam kalimat-kalimat hukum. Di satu sisi kalimat hukum itu terlalu berlebihan karena selalu diulang-ulang kalimatnya. Di sisi lain ada juga kalimat yang subjeknya dilesapkan, dengan tidak disebutkan lagi karena dalam logika hukum subjek kalimat tersebut sudah dianggap dipahami oleh semua orang.

\section{DAFTAR PUSTAKA}

Abdulman. 2011. Study Morfosintaksis tentang Pemakaian Verba Transitif dalam Al Quran Surat AlKahfi. Retrieved from http://repository.upi.edu.

Ba'dulu, A. M. 2005. Morfosintaksis. Jakarta: Rineka Cipta.

Badudu, J. S. 1988. Cakrawala Bahasa Indonesia. Jakarta: Gramedia.

Bloomfield, L. 1993. A. Course in Basic Grammatical Analysis. Tucson USA: Summer Institute of Linguistics.

Hartini, L. 2019. Bahasa dan Produk Hukum. Bandung: Refika Aditama.

Indonesia, B. P. dan P. B. R. 2015. Pedoman Umum Ejaan Bahasa Indonesia. Jakarta.

Indonesia, D. P. dan K. 1988. Tata Bahasa Baku Bahasa Indonesia. Jakarta: Balai Pustaka.

Iskar, S. 2004. Pembakuan Kosa Kata Indonesia. Retrieved from http://www.pikiranrakyat.com/cetak/0504/02/khazanah/wisatabahasa.htm

Ramlan. 2005. Sintaksis. Yogyakarta: Karyono. 